\title{
Third Grundtvig International Conference on Education, Communication and Development, India 2007
}

\author{
By Asoke Bhattacharya
}

The Third Grundtvig International Conference on Education, Communication and Development was held in India from 8-16 January 2007. The major conference was held from 8-11 January at Kolkata in the premises of the Indian Museum. It was followed by a workshop at Mitraniketan, Kerala from 15-16 January. This conference and workshop, possibly for the first time, brought together educationists, intellectuals, politicians and policy-makers of education, communication and development from various parts of India and different countries around the world in a series of brain-storming sessions spanning over a period of six days at two different Indian locations. The conference and workshop were held with active collaboration and support of the Centre for Grundtvig Studies, University of Aarhus.

\section{Genesis}

The first two Grundtvig International Conferences were held at Jadavpur University, Kolkata in 1999 and 2003. Participants were mainly academicians and students. Although the conferences were very successful, it was felt that the message was confined within the educational community of the Universities only.

During the preparation of the conference in 2006 efforts were made to present Grundtvig to the people at large, especially those working in the field of literacy and enlightenment. It was also felt that experts in the field of people's education belonging to various states of India, who were not yet exposed to the thoughts of Grundtvig, would be invited so that they were acquainted with Grundtvig's revolutionary ideas.

Simultaneously J. H. Schjørring, Director of the Centre for Grundtvig Studies, University of Aarhus endeavoured to gather as many experts in the fields as possible from various countries of the world.

\section{Preparation}

Since the objective was to associate as many organisations and individuals as possible, especially those engaged in the field of education, communication and development, the organisers contacted various 
state and central government agencies, autonomous but government aided institutions, NGOs and a large number of individuals who could be associated with this international venture. The main responsibility of organising the Kolkata conference was jointly shouldered by Satyen Maitra Janasiksha Samity and the Grundtvig India Society for Popular Enlightenment and Human Development. The Mass Media Centre, Government of West Bengal, actively cooperated by allowing the organisers to use its premises, halls and infrastructure for a period of six months and cooperated in accessing the press corps of Kolkata. The Indian Adult Education Association (IAEA), the largest and oldest organisation in India working for adult literacy and people's development collaborated in organising the conference. The Institute of Mass Communication, Film and Television Studies affiliated to the University of Kalyani pledged full support. The Folk High School in Mitraniketan in Kerala, which has extensive contacts with Denmark, readily agreed to undertake organisation of a two-day workshop there.

The Centre for Grundtvig Studies, University of Aarhus cooperated at every stage of preparation of the conference.

\section{Theme}

From the very outset, it was discussed and agreed upon that the themes of the conference would be such that Danish and other international experts from the relevant fields would be able to interact with Indian experts and participants regarding relevance of Grundtvig's thoughts for Indian and Third World reality. Efforts were made to ensure that Indian and foreign participants were sensitised about the common issues so that they could discuss the common objectives. The following themes were finalised:

1. Contribution of Grundtvig, Freire and Tagore in adult and continuing education and their relevance in the present context

2. Globalisation and the new dimension in people's education

3. Historical background and the present trend in adult education

4. Satyen Maitra and adult education in India

5. Education, Development and change

6. Adult education, democracy and participatory development

7. Democracy game

8. A structural model for non-formal education in the third world - with specific reference to India

9. Enlightenment in the Danish Golden Age and the Bengal Renaissance: Grundtvig and Kierkegaard, Vidyasagar, Tagore and Vivekananda 
10. Role of the rural press in promotion of literacy, women's empowerment and rural development.

\section{Collaboration}

The following scholars from Denmark attended the conference: J. H. Schjørring, Ove Korsgaard, Søren Ehlers, Harry Haue, Rikke Schultz, Jakob Erle, Kirsten Bruun, Ulrik Overgaard, Ulla Bidstrup, Uffe Jonas and Mette Geil. Mark Mattes from Grand View College, USA was an important addition to the contingent. Lidia Shkorkina (Russia) and Munetaka Tabuchi (Japan) each added a significant geographical area. There were participants from various parts of India: Dr. B. G. Bokil from Maharastra, A. H. Khan from Bihar, Daniel Jayakumar from Tamil Nadu. 127 representatives from various districts of West Bengal participated in the conference. Beside the speakers, there were 20 guests in attendance. 65 volunteers worked round the clock to make the conference a success. There were 13 sub-committees taking care of such matters as accommodation, food, cultural programmes, transport, exhibitions and souvenirs. Pratap Chandra Chandra, former Union Minister of Education, was chairman of the organising committee. There were 5 vice-chairpersons and 40 advisors who looked after the day to day functioning of the organising committee. Special mention must be made of The Indian Museum, a 200-year-old institution, for generously placing its halls and entire premises at the disposal of the organisers of the conference and associated exhibition. Above all, tribute must be paid to the central facilitating role played by Professor J. H. Schjørring of the Centre for Grundtvig Studies, University of Aarhus, without whose untiring efforts throughout the planning stages the objectives of the conference could not have been achieved.

\section{Conference in Kolkata}

The conference started in Kolkata on 8 January 2007. Though there was a strike call in the city over a local issue, the conference began at the scheduled hour. Asoke Bhattacharya welcomed the guests and set the tone of the conference by mentioning the wide participation of delegates from various corners of the state, nation and the world.

The inaugural address was delivered by Pratap Chandra Chandra, former Union minister of education. Narrating his own experience in the field of education, the octogenarian leader suggested that for people's educational initiatives, newspapers should come out with supplements for the neoliterates. Kshiti Goswami, Minister in charge of Public works of West Bengal stressed the need of people's 
enlightenment in the backdrop of growing obscurantism in the country and the state. J. H. Schjørring, who was the special guest at the inaugural function, took stock of the progress made during the course of the three Grundtvig International Conferences held in Kolkata in 1999, 2003 and 2007. The participant group from India had become wider, he observed. The international presence was also broader than the earlier two occasions, he said. Speaking as the guest of honour, Ove Korsgaard, President of the Association of World Education stressed the need for life-long learning.

The afternoon session was held simultaneously at two different venues and dealt with two separate themes: (1) Contributions of Grundtvig, Freire and Tagore in adult and continuing education and their relevance in the present context; (2) Democracy game.

The first theme saw lively exposition of the concept of 'enlightenment' and 'people' by Ove Korsgaard. Daniel Jayakumar said that along with Grundtvig, Tagore, Freire and Gandhi based their ideals of education on the sovereignty of the people. Lidia Shkorkina from Russia, the chief guest, described the initiatives taken in Russia to study and implement Grundtvig's concept of enlightenment.

Democracy game was introduced and conducted by Jakob Erle in an attractive manner. The game, he explained, involved four elements: challenges, power, participation and dealing with challenges through power controlled by participation. The players, divided into three groups from among the participants, played the game with great enthusiasm as they sorted out flash-cards with a problem-solving approach at four levels - local, national, regional and global.

A grand exhibition on various aspects of special, non-formal and vocational education as well as development communication was organised in the conference premises. Among participating organisations were The Blind Persons' Association, Kaibarta Samity (a women's self-help organisation) and The West Bengal University of Animal and Fishery Science. An assembly of folk artists exhibited their work at Gurusaday Dutta Artisan Gallery.

The second day of the conference started with the spirit of active participation and enthusiastic interaction. The morning session had two themes at two venues: (1) Globalisation and new dimension of people's education; (2) Historical background and the present trend in adult education. In the afternoon session two more themes were discussed: (1) Satyen Maitra and adult education in India; (2) Education, Development and Change.

The first theme of the morning session was chaired by P. R. Das, Executive President of The Grundtvig Society for Popular Enlightenment and Human Development, Kolkata. The chief guest Søren Ehlers 
answered the moot question raised by the focal theme: What is the new dimension in people's education, after all? It was, he explained, "lifelong learning for everybody, not excluding anybody."

Delivering the keynote address, Mark Mattes detailed how Grundtvig, in his time, added this new dimension in people's education. Grundtvig was deeply concerned with the renewal of Christianity in Denmark, but only in the light of the renewal of the human spirit, he said, reminding the Indian participants of Vivekananda's observation on the renewal of Hindu society.

Partha Dey, Minister in charge of school education in West Bengal, placed this new dimension of people's education in the context of the present era of globalisation. In a lively interaction, one of the speakers, Afzal Hussain, sought clarification regarding inner meaning of 'learning' and 'education'. Søren Ehlers answered that while learning was transnational, education was more national.

The second theme of the morning session was "Historical background and the present trend in adult education". Addressing as chief guest, Jakob Erle said that without people's participation, there would be no people's education in the proper sense of the term. Amalendu De, Chairman, dwelt at length on the history of mass education in India from the pre-colonial times. Even before the advent of the British rule, efforts had started in the country to provide education to a wide cross-section of the common people through numerous 'pathsalas' and 'maktabs' (primary schools). In the early days of the colonial rule, some of the missionaries and enlightened Britons tried to sustain and patronise such a system of education. But the imperial rulers did nothing to back it up since they wanted only a lean educated middle class who would serve as cogs in the wheel of the colonial system, he said.

Jayanta Ghosal, another speaker representing The Indian Adult Education Association, said that bureaucratic practices were standing in the way of people's education in India.

The third session in the afternoon heard an animated discussion on why pioneers like Satyen Maitra, despite their lifelong efforts, could not have a decisive influence on educational policy in India. Sakti Mandal, the keynote speaker and the secretary of the conference organising committee, explained why Maitra's efforts to introduce popular education met with resistance: firstly because he was not in favour of a static system and secondly, Maitra used an unconventional method.

The fourth session on education, development and change was chaired by the Vice-Chancellor of The West Bengal University of Animal and Fishery Sciences, Chandrasekhar Chakraborty. A brilliant 
keynote address was delivered by Mette Geil. The session was chaired by Daniel Jayakumar. Munetaka Tabuchi of Japan spoke in this session.

The topics of discussion on the third day were: (1) A structural model for non-formal education in the third world - with special reference to India; (2) Adult education, democracy and participatory development.

Presenting the keynote address on the first topic, Asoke Bhattacharya gave an overview of the Indian literacy movement in the recent times. He suggested a structured model for India:

- At the village level, people's basic school

- At the block level, people's high school

- At the district level, people's college.

All these institutions would be coordinated by a rural university. This model, said Bhattacharya, was built upon Grundtvig's idea of folk high school and specific experience in people's education in West Bengal.

Lidia Shkorkina from Russia threw light on the process by which such endeavours in implementing the basic tenets of people's education in a specific historical-cultural context could advance towards success.

Kanti Biswas, former minister of school education of West Bengal, said that 10 January, the third day of the conference, had a historical significance since the League of Nations came into being on that day. Even after so many years of international and national initiative, the global literacy rate was $80 \%$ by the end of 2006 , he lamented. India was home to 34.6 percent of the world's illiterate population. India ranked 100th among 121 countries in terms of Education Development index.

The second session was chaired by Harry Haue. He also delivered the keynote address on the topic 'Globalisation and new dimension of people's education'. After a brief introduction of the rural development and the corresponding evolution of the education system in Denmark, he made a comparative and relational analysis:

- Between national and international spheres of education

- Between text and dialogue

- Between mind and heart.

He categorised knowledge at three levels:

- Knowledge of the first order $\rightarrow$ qualification

- Knowledge of the second order $\rightarrow$ knowledge of using Knowledge $\rightarrow$ competence

- Knowledge of the third order $\rightarrow$ knowledge of knowledge $\rightarrow$ reflection. 
Rikke Schultz's lecture made it clear that knowledge at all three levels must be communicated to the people at appropriate phases for fulfilment of their enlightenment. "Democracy can only function if the people are enlightened", she emphasised, urging, "Tell people why, and they will find how and what to do by themselves".

Ulrik Overgaard dealt with the crucial question: " How to impart Grundtvig's ideas on non-formal education in a new reality?" Teachers, he said, had to be relevant, entertaining and understandable.

The subjects of discussion on the fourth day were: (1) Enlightenment in the Danish Golden Age and the Bengal Renaissance: Grundtvig and Kierkegaard - Vidyasagar, Tagore and Vivekananda; (2) Role of the rural press in promoting literacy, women's empowerment and rural development.

Uffe Jonas chaired the first theme of the session. Ulla Bidstrup delivered the keynote address. The Danish Golden Age, Bidstrup said, extended from 1800 to 1849 . At that time, it had made an impact on the middle and higher classes. It drew heavily on the Romantic movement and there was a marked interest in folk traditions. Many artists and writers emerged in the course of new awakening. The most important question that emerged during this period was what could be the common language of the Danes. Danish was the people's choice. A high point was the singing of Christian songs in Danish.

There was much interest in the folk songs of Bengal in Europe, particularly in Denmark, in the nineteenth century. During the Bengal Renaissance, Vidyasagar's experiments to popularise education through the mother tongue also had keen watchers among the Danes.

Atish Dasgupta spoke on the literacy movement in Bengal. He mentioned the role of the freedom fighters and social workers in the campaign. Tapas Chatterjee compared the social situation prevalent in Europe and Bengal during the renaissance periods. Subir Bandyopadhyay recalled Vidyasagar's saying that there could be no social education without mass education. He also mentioned the contribution of Vivekananda's Vedanta and the role of Tagore as the father of modern Bengali language.

Uffe Jonas highlighted the common thread in the thoughts of Grundtvig and Vivekananda since both of them laid emphasis upon the centrality of motherly love and affection. People's education could achieve much success if it had the support of this emotion flowing from women's hearts.

The second theme-session was chaired by Biswajit Matilal. Subir Ghosh presented the keynote address. He underlined the need for mass communication which generates awareness for education, environment and other important social issues. Atanu Sarkar laid stress upon health 
education and women's empowerment as the focal points in the presentation of news by the media. Small newspapers, Samir Goswami pointed out, could play an effective role in mass communication in rural areas. Salil Dasgupta said that rural development should constitute an important part of media coverage.

In the concluding session, chaired by Bikash Ranjan Bhattacharya, Mayor of Kolkata, J. H. Schjørring delivered his address as the special guest.

There were numerous cultural programmes before and after the sessions.

Workshop on educational thoughts of Grundtvig, Gandhi and Tagore: Mitraniketan, Kerala, India, 15-16 January 2007

The workshop was inaugurated by T. Madhava Menon, former ViceChancellor, Kerala Agricultural University. K. Viswanathan, Director of Mitraniketan, presided. The keynote address was delivered by Harry Haue.

The first session on 15 January 2007 saw the presentation of four papers: Tagore - Philosophy and practice by C. Nazeema, Dean, Faculty of Education, University of Calicut; Grundtvig and the link to life-long learning - from local to global by Søren Ehlers; Tagore and Gandhi as educational revolutionaries by N. Radhakrishnan, Honorary Ambassador, Soka University of America; and Denmark and India: impact of enlightenment in the Danish context by Jakob Erle.

The second session had the following topics and speakers: A greenhouse for skills and citizenship - a practical example by Kirsten Bruun; Story-telling in the Grundtvigian tradition and now by Ulrik Overgaard; and Antyodaya of farm labourers by V B Padmanathan. Mani, a former priest, gave an interesting speech on people's enlightenment.

The third session saw the following presentations: Gandhi's gift to the nation by D. Janardan Reddy of S. V. University, Tirupati; Grundtvig and nationalism by Munetaka Tabuchi of Nagoya University, Japan; National identity and international community European challenges after 1989 by J. H. Schjørring; and Edu-game by Jakob Erle.

The fourth session on 16 January 2007 went as follows: Educational thoughts of Gandhi - their relevance today by A. Mariappan, Chairman, Gandhi Smarak Nidhi, Madurai; Grundtvig and Gandhi - a comparative analysis by Asoke Bhattacharya, Head of the Department of Adult, Continuing Education and Extension, Jadavpur University, Kolkata; Folk culture, mother tongue and education - Grundtvig and 
Tagore by Ulla Bidstrup; and the School for Passion - Grundtvig's creative concept of enlightenment by Uffe Jonas.

The fifth session saw the following presentations: The rural agricultural work experience - an experiential learning program by Prakash of the College of Agriculture, Kerala; Doing Grundtvig in context - future challenges in education by Mette Geil; and Tagore's educational philosophy and its relevance today by Sakti Mandal of Satyen Maitra Janashiksha Samiti, Kolkata.

The sixth and concluding session saw Harry Haue's presentation on Grundtvig and globalisation; and Jens Karlsson's Swedish Folk High School system - an analysis.

There were lively discussions after each session. 